\title{
(6) OPEN ACCESS \\ Can psychosocial work conditions protect against age-related cognitive decline? Results from a systematic review
}

\author{
Mette Andersen Nexø, Annette Meng, Vilhelm Borg
}

The National Research Centre for the Working Environment, Copenhagen, Denmark

\section{Correspondence to} Dr Mette Andersen Nexø, The National Research Centre for the Working Environment, Lersø Parkallé 105,

Copenhagen DK-2100, Denmark; man@nrcwe.dk

Received 5 January 2016 Revised 18 April 2016 Accepted 26 April 2016 Published Online First 13 May 2016

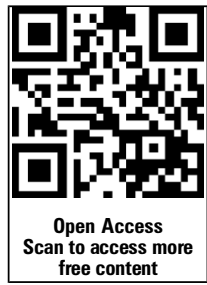

CrossMark

To cite: Nexø MA, Meng A, Borg V. Occup Environ Med 2016;73:487-496.

\section{ABSTRACT}

According to the use it or lose it hypothesis, intellectually stimulating activities postpone age-related cognitive decline. A previous systematic review concluded that a high level of mental work demands and job control protected against cognitive decline. However, it did not distinguish between outcomes that were measured as cognitive function at one point in time or as cognitive decline. Our study aimed to systematically review which psychosocial working conditions were prospectively associated with high levels of cognitive function and/or changes in cognitive function over time. Articles were identified by a systematic literature search (MEDLINE, Web of Science (WOS), PsycNET,

Occupational Safety and Health (OSH)). We included only studies with longitudinal designs examining the impact of psychosocial work conditions on outcomes defined as cognitive function or changes in cognitive function. Two independent reviewers compared title-abstract screenings, full-text screenings and quality assessment ratings. Eleven studies were included in the final synthesis and showed that high levels of mental work demands, occupational complexity or job control at one point in time were prospectively associated with higher levels of cognitive function in midlife or late life. However, the evidence to clarify whether these psychosocial factors also affected cognitive decline was insufficient, conflicting or weak. It remains speculative whether job control, job demands or occupational complexity can protect against cognitive decline. Future studies using methodological advancements can reveal whether workers gain more cognitive reserve in midlife and late life than the available evidence currently suggests. The public health implications of a previous review should thereby be redefined accordingly.

\section{INTRODUCTION}

An ageing workforce challenges most Western countries $^{12}$ and calls for new strategies to prevent older workers from retiring early. Cognitive abilities are central in mental health, and even milder forms of cognitive decline impact daily function and well-being. ${ }^{3}{ }^{4}$ Despite important public health implications, it remains poorly understood how age-related cognitive decline impacts the ability to perform at work.

Like the body, the brain ages. A marked cognitive decline is observed around the age of 50 years. ${ }^{5-7}$ It is mostly observed in fluid cognitive abilities such as working memory, episodic memory, reasoning abilities and processing speed. Crystallised abilities, for example, knowledge acquisition, are more resistant to age-related decline. ${ }^{8}$
The modern labour market is increasingly characterised by jobs requiring cognitive rather than physical skills. ${ }^{9}$ Most of today's work tasks represent some kind of mental challenge irrespective of whether it is advising a patient, interpreting a customer's needs or operating a machine. Highly mentally challenging jobs often require that the employee is able to process and organise a constant stream of complex information, adjust to new technologies and be creative and innovative. ${ }^{10}{ }^{11}$

In accordance with the 'use it or lose it' hypothesis, ${ }^{12}$ the number of hours spent every day performing mentally complex tasks can strengthen an individual's cognitive capacity. Workers who have mentally complex jobs may experience a slower rate of cognitive decline than those who do not. According to Karasek's ${ }^{13}$ demand control model, the beneficial effects of complex mental work demands also depend on an employee's level of job control or decision latitude. A work environment characterised by a high level of work demands and control fosters psychological well-being. This combination is characterised as an 'active job' and may advance cognitive function. ${ }^{14}$ Conversely, jobs characterised by a high degree of work demands combined with a low level of control incur psychological strain, which may lower cognitive function. ${ }^{15}$

However, the brain reserve theory suggests that it is the combination of congenital brain capacity and development of cognitive ability early in life that mainly accounts for an individual's level of cognitive function throughout the life course. ${ }^{16}$ This theory assumes that individuals have a high level of cognitive function in late life because they had a high level of cognitive function in early years; nevertheless, the rate of cognitive decline over time is the same regardless of the level of cognitive function in early life. This phenomenon is also referred to as 'preserved differentiation'. By contrast, evidence of 'differential preservation' would require that specific environmental conditions could influence the level of cognitive function and the rate of cognitive decline. ${ }^{12} 17$

Cognitive reserve is considered another supplementary reserve, which considers how the brain is able to compensate for age-related changes, damage or pathology. ${ }^{18}$ An individual's level of cognitive function is reflected by prior cognitive level but can also be improved by experiences later in life such as education or a mentally challenging job. ${ }^{19}$

To date, only one systematic review has examined the association between psychosocial working conditions and cognitive ageing. Then et $a l^{20}$ 
Table 1 Overview of inclusion and exclusion criteria

\begin{tabular}{|c|c|c|}
\hline & Inclusion criteria & Exclusion criteria \\
\hline Population & $\begin{array}{l}\text { Employees exposed to } \\
\text { psychosocial working conditions } \\
\text { in midlife or late life (minimum } \\
40 \text { years) }\end{array}$ & $\begin{array}{l}\text { Diseases, disorders or medical } \\
\text { conditions (eg, brain diseases } \\
\text { or dementia) }\end{array}$ \\
\hline Design & $\begin{array}{l}\text { Longitudinal studies: } \\
\text { observational cohort studies, } \\
\text { case-control or randomised } \\
\text { controlled trials }\end{array}$ & $\begin{array}{l}\text { Cross-sectional studies, case } \\
\text { studies, discussion papers, } \\
\text { reviews, meta-analyses }\end{array}$ \\
\hline Exposures & $\begin{array}{l}\text { Psychosocial working conditions } \\
\text { (eg, working hours, } \\
\text { psychological work demands), } \\
\text { work environment factors } \\
\text { (eg, job control) }\end{array}$ & $\begin{array}{l}\text { Chemicals (eg, solvents, } \\
\text { manganese) physical demands, } \\
\text { psychological distress }\end{array}$ \\
\hline Outcomes & $\begin{array}{l}\text { Levels of cognitive function or } \\
\text { changes in cognitive function } \\
\text { over time (eg, age-related } \\
\text { cognitive decline) }\end{array}$ & $\begin{array}{l}\text { Outcomes with no clear } \\
\text { definition of cognitive function } \\
\text { (eg, psychological health, } \\
\text { psychological stress, depressive } \\
\text { symptoms) }\end{array}$ \\
\hline
\end{tabular}

conclude that psychosocial work conditions such as complexity of work and job control can protect against cognitive decline and dementia. The evidence to support the conclusions of the review is partly based on studies that measure cognitive function at one point in time 2122 and, in our view, therefore not sufficient to support the notion that work conditions can protect against decline of cognitive abilities. ${ }^{12}{ }^{17}$ Without evidence of differential preservation, prior levels of cognitive function or education remained important confounders that could explain the higher level of cognitive function among individuals with a mentally complex job or a high level of job control.

A re-evaluation of the evidence from these alternative methodological perspectives could provide crucial evidence that either strengthens or refines the previous public health implications of Then et al's results. This study aimed to systematically review the evidence that addresses following research question: Which psychosocial working conditions are prospectively associated with individuals' levels of cognitive function and/or changes in cognitive function over time?

\section{METHODS}

This study was a systematic review following the general principles of the Preferred Reporting Items for Systematic Reviews and Meta-Analyses (PRISMA). ${ }^{23}$

\section{Search strategy}

A systematic literature search was undertaken by a librarian at the National Research Centre for the Working Environment. The search string was defined by our inclusion/exclusion criteria (table 1) and adapted to the interfaces of four databases:

- MEDLINE via the PubMed interface: http://www.ncbi.nlm. nih.gov/pubmed

- PsycNET via the APA host interface: http://psycnet.apa.org/

- Web of Science includes the three databases-Science Citation Index Expanded (SCI-EXPANDED), Social Sciences Citation Index (SSCI) and Arts \& Humanities Citation Index (A\&HCI) - and was searched via the host interface: http:/ apps.webofknowledge.com/

- OSH UPDATE includes the databases CISDOC, HSELINE, NIOSHTIC and RILOSH and was searched via the host interface: http://www.oshupdate.com/
The search included articles published until 1 August 2014. Articles were also identified by screening studies from reference lists of other relevant articles and reviews ${ }^{20}$ and references recommended by colleagues within the field.

This study was part of a research project addressing three research questions. The systematic search therefore also included studies concerning all the research questions. This article reports findings regarding only the research question about work conditions and cognitive ageing.

\section{Inclusion and exclusion criteria}

We included articles written in English and studies measuring psychosocial work exposures in midlife or late life (table 1). Owing to risk of reverse causation, we included only studies with a longitudinal design with at least one follow-up measurement of cognitive function. We aimed to review evidence in working populations and therefore excluded studies that examined cognitive decline in clinical populations-for example, dementia. We regarded psychological distress as a reaction to, rather than an exposure to, an environmental strain and therefore also excluded studies examining the impact of psychological distress on cognitive ageing.

\section{Data extraction}

We extracted information about each study's populations (nationality, age, selection criteria, number of participants), the number of waves and total follow-up in years. We distinguished between outcomes that were measured as levels of cognitive function at one point in time and/or outcomes that were measured as changes in levels of cognitive function over time (cognitive ageing). We also extracted how the outcomes were measured and information regarding the studies' results, statistical methods and the significance level ( $\mathrm{p}$ value or $\mathrm{CI}$ ).

\section{Quality assessment}

We developed a quality assessment checklist based on checklist items from existing guidelines (box 1). ${ }^{23-25}$ We included items from the checklists according to three overall quality criteria: the transparency of the applied theory, aims and methods; the quality of the available data sources and materials and the applicability of the results; and the quality of the way the available data sources were applied in the study.

We applied a scoring system of $0-10$ points ( 0 indicating the worst quality and 10 the best quality). Points were given if the researcher could answer 'yes' to the checklist $(1=$ yes, $0.5=$ partially, no $=0$; box 1 )

All studies included were cohort studies. We therefore put forward specific criteria that needed to be fulfilled to achieve points (labelled '\#'; box 1). Since the studies were mainly longitudinal cohort studies, most of these criteria addressed the weaknesses specific to observational study designs. ${ }^{23-27}$

\section{Study procedure}

Three researchers (MAN, AME and VBO) carried out the systematic review from May 2014 to August 2015. The researchers had postdoc research experience ranging from 1 to 25 years. Two reviewers compared title-abstract screenings and full-text screenings for eligibility. The quality of each study was assessed independently by two researchers. The ratings were then compared. Discrepancies in ratings were first discussed and if necessary resolved by a senior researcher. Every study was categorised according to the final score: high quality (8-10 points), moderate quality (6-7.5 points), low quality (4-5.5 points) or very 


\section{Box 1 Quality assessment checklist}

Questions to assess the quality of the way the information is reported

1. Did the study clearly describe mechanism/theoretical assumptions in relation to the aims? ( $0-1$ point)

2. Did the study address a clearly focused issue? (0-1 point)

3. Was the design and method clearly described?

- \# Exact number of participants at each follow-up? (0-0.5* point)

- \# Information about differences between dropouts and participants? (0-0.5* point)

Questions to assess the quality of the available data sources

4. Was the cohort recruited in an acceptable way and in a way that minimised risk of selection bias? (0-1 point)

5 . Was the participation rate acceptable?

- \# Minimum $70 \%$ ? (0-1 point)

6 . Were the exposures and outcomes accurately measured to minimise measurement bias? $\left(0-0.50^{*}\right.$ point)

- \# Cognitive function measured by standardised cognitive tests $\left(0-0.5^{*}\right.$ point $)$

Questions to assess the quality of the way the available data sources are applied in the study

7. Was dropout attended to by, for example, dropout analysis or sensitivity analysis? (0-1 point)

8. Inclusion of appropriate confounders

- \# Educational level/socioeconomic status $\left(0-0.5^{*}\right.$ point $)$

- \# Pathology $\left(0-0.5^{*}\right.$ point)

Questions to assess the applicability of the results

9. Was it possible to interpret the results without bias or confounders?; applicability of results considering strengths and limitations ( $0-1$ point)

10 . Were the results plausible according to the aims, theoretical mechanisms, study context and previous literature? (0-1 point)

- Strength of association according to statistical power and significance levels/Cls

- Bradford Hill's criteria (time sequence, dose-response gradient, plausibility, consistency)

Accumulated points:

Questions to assess the quality of the way the information is reported (questions $1+2+3$ ) $0-3$ points:

Questions to assess the quality of the available data sources (question $4+5+6+9+10$ ) $0-5$ points:

Questions to assess the applicability of the results (question 7

+8) $0-2$ points:

Total points (0-10):

Rating of the answers to the questions: 'yes' $=1$ point;

'partially' $=0.5$ point; 'no/information' not available $=0$ points.

* Answering 'yes'only gives 0.5 point because it is a

subquestion.

\# Criterion must be fulfilled to get points.

low quality ( $0-3.5$ points). Only studies of moderate and high quality were included in the final synthesis of evidence.

\section{Synthesis of evidence}

The strength of the evidence was evaluated according to four levels: strong evidence: consistent findings from a minimum of two studies of high quality; moderate evidence: consistent results from two studies of moderate quality or consistent results from one study of high quality and one study of moderate quality; weak evidence: findings from one study of moderate or high quality; conflicting evidence: findings from at least one study of moderate or high quality that pointed in one direction and findings from a minimum of $33 \%$ of all studies of moderate or high quality that pointed in another direction; no evidence: consistent findings of no significant associations from minimum two studies of high or moderate quality; insufficient evidence: no studies of high or moderate quality that have examined the association.

\section{RESULTS}

From the 1845 identified articles, 1799 were excluded by screening titles or abstracts and 46 full-text articles were assessed for eligibility (figure 1). Of these, 24 articles were excluded mainly because of cross-sectional study designs or because stress was the chosen outcome. Of the 22 studies included for quality assessment, 11 were of moderate or high quality and therefore included in the final synthesis of evidence.

All the studies were cohort studies. We categorised the studies according to the kind of psychosocial work conditions to which the employees had been exposed (table 2):

- Mental work demands $(n=4)$ : Mental work demands or $\operatorname{cog}$ nitive stimulation refer in these studies to the various mental activities required by the work tasks of a specific job. The demands were mostly measured as the employees' selfreported level of mental work demands.

- Work complexity $(n=2)$ : These studies classified complexity in accordance with the 'US classification'. This system has allocated a code (Dictionary of Occupational Titles) to each job title based on job analyst's ratings on the nature and content of different jobs. On the basis of job titles, the level of complexity of an individual's job is grouped into three categories: complexity of work with data, people or things. ${ }^{28} 29$

- Work environmental factors $(n=5)$ : Of these, three studies examined exposure to different dimensions of Karasek's ${ }^{13}$ demand-control model, one organisational justice and one working hours.

\section{Review of studies measuring exposure to mental work demands}

Four studies ${ }^{22}$ 30-32 examined whether a high degree of mental work demands influenced cognitive function or cognitive decline (table 2).

Fisher $e t a l^{30}$ showed in a large sample of nationally representative adults that work demands moderated the level and rate of change of episodic memory before and after retirement. Over an 18-year period, individuals in jobs characterised as highly mentally challenging had higher levels of cognitive function and a slower rate of decline than did individuals in jobs characterised as minimally mentally challenging.

Marquie $e t a l^{31}$ showed that participants who experienced a high degree of cognitive stimulation at work were associated with a higher cognitive function than were participants who experienced a lower level of cognitive stimulation. Within the first 5 years of the study period, all participants, regardless of the level of cognitive stimulation, improved their cognitive performance. This result was ascribed practice effects from the cognitive tests. In the subsequent 5 years, only participants who had a low level of cognitive stimulation at work exhibited accelerated cognitive decline.

Gow $e t a l^{32}$ found that individuals who had an intellectually stimulating job performed worse on cognitive tests than did those whose job involved manual labour after adjusting for 
Figure 1 Flow chart of the systematic literature search and review process. OSH, Occupational Safety and Health.

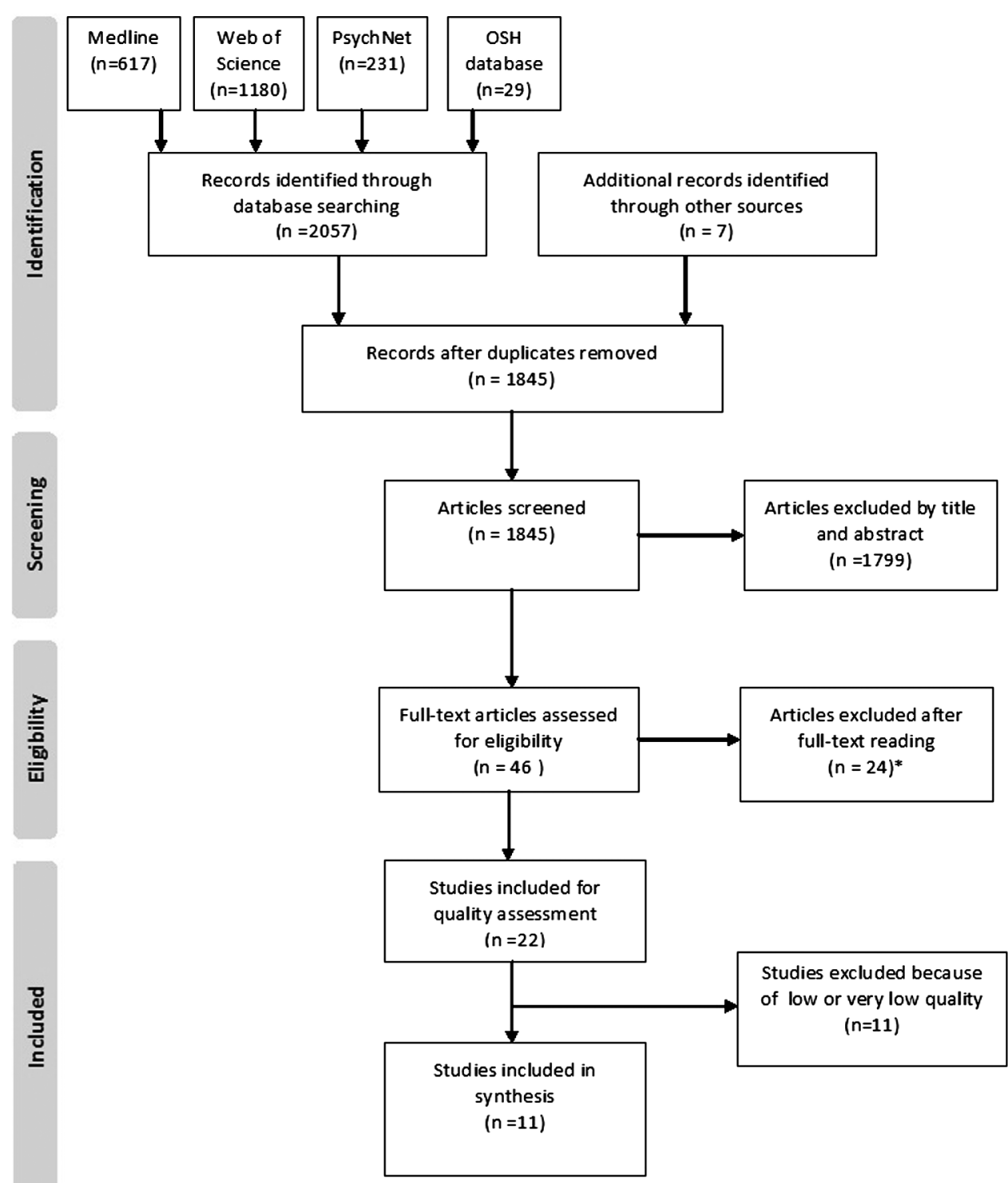

*Articles were excluded mainly because of cross sectional research designs or stress related outcomes. Three studies addressed research aims related to the research project's two other systematic reviews

general cognitive ability at baseline. Over a 30-year period, they found no effect of having a job that was experienced as cognitively stimulating on change in level of cognitive function.

Bosma et $a l^{22}$ showed that participants in jobs with a high level of self-reported job demands were less likely to perform within the lowest 10 th centile of composite cognitive test score at a 3-year follow-up.

\section{Synthesis of evidence}

Two studies of high quality ${ }^{30} 31$ and one study of moderate quality $^{22}$ provided strong evidence that workers in jobs with a high level of mental work demands were prospectively associated with a high level of cognitive function. One study of moderate quality ${ }^{32}$ showed the opposite effect. Since this study accounted for $<33 \%$ of the results, it did not affect the final synthesis of evidence.

We found conflicting evidence as to whether mental work demands could protect against cognitive decline. Two studies of high quality ${ }^{30} 31$ provided strong evidence that mental work demands slowed the rate of cognitive decline. One study of moderate quality ${ }^{32}$ provided weak evidence that mental work demands had no effect on cognitive decline.

\section{Review of studies examining exposure to occupational complexity}

Two studies ${ }^{33} 34$ examined the impact of the substantial complexity of work on cognitive function or cognitive decline (table 2).

Finkel et $a l^{33}$ examined how occupational complexity affected cognitive decline in a Swedish cohort of adopted twins before and after retirement. They found significant effects for only complex work with people and not with data or things. They found no differences in levels-or decline of episodic memory. In the period up until retirement, employees who had highly complex work performed better on tests assessing verbal and spatial ability, and processing speed and showed a slower rate of decline of verbal ability compared with employees who had a low level of occupational complexity. Although individuals retired from jobs with highly complex work scored higher on tests assessing spatial ability, they observed an accelerated decline of this ability after retirement. No significant differences 
Table 2 Data extraction of studies included in synthesis $(n=11)$

\begin{tabular}{|c|c|c|c|c|c|c|}
\hline $\begin{array}{l}\text { Study } \\
\text { Author, } \\
\text { year; } \\
\text { country }\end{array}$ & $\begin{array}{l}\text { Population (age, } \\
\text { inclusion criteria, } \\
\mathrm{n}=\text { number of } \\
\text { participant) }\end{array}$ & Exposure (categories) & $\begin{array}{l}\text { Follow-up in } \\
\text { years (FU) } \\
\text { Waves: year } \\
\text { (T=time, } \\
\text { T0=baseline) }\end{array}$ & $\begin{array}{l}\text { Outcome measurements } \\
\text { Cognitive domain (type of } \\
\text { cognitive test) }\end{array}$ & $\begin{array}{l}\text { Statistical tests and included } \\
\text { covariates (variables) }\end{array}$ & $\begin{array}{l}\text { Results: level of cognitive } \\
\text { function } \\
\text { NS: non-significant results, } \\
p<0.05\end{array}$ \\
\hline \multicolumn{7}{|c|}{ Studies examining mental work demands } \\
\hline $\begin{array}{l}\text { Fisher et al } \\
2014 ;{ }^{30} \\
\text { USA }\end{array}$ & $\begin{array}{l}\text { Health and retirement } \\
\text { study: employees aged } \\
51 \text { to } 61 \text { retired before } \\
\text { 1998, } n=4182\end{array}$ & $\begin{array}{l}\text { Mental work demands } \\
\text { (O*NET rating scale) }\end{array}$ & $\begin{array}{l}\text { FU: } 18 \text { years } \\
\text { Four waves: } \\
\text { T1 1992; } \\
\text { T2 1998; } \\
\text { T3 2004; } \\
\text { T4 2010 }\end{array}$ & $\begin{array}{l}\text { Levels of and changes in } \\
\text { Episodic memory (immediate and } \\
\text { delayed recall) } \\
\text { Mental status (TICS) }\end{array}$ & $\begin{array}{l}\text { Latent growth curve model } \\
\text { (health status, depressive } \\
\text { symptoms, demographic } \\
\text { characteristics, retirement, } \\
\text { practice effects) }\end{array}$ & $\begin{array}{l}\text { Greater mental work demands } \\
\text { associated with higher levels of } \\
\text { episodic memory (intercept } 0.06 \text {, } \\
p<0.05,40 \% \text { of the variance) and } \\
\text { better mental status (intercept }=0.11 \text {, } \\
p<0.05 \text { ) before retirement at T1-T4 }\end{array}$ \\
\hline
\end{tabular}

$\begin{array}{llll}\text { Marquie } & \text { VISAT longitudinal study: } & \text { Cognitive stimulation at } & \text { FU: } 10 \text { years } \\ \text { et al, } & \text { random sample } 94 & \text { work (seven-item scale) } & \text { Three waves: } \\ \text { 2010; } & \text { occupational physicians, } & & \text { T1 1996; } \\ \text { France } & \text { aged 32-62 years, } & & \text { T2 2001; } \\ & n=3237 & \text { T3 2006 }\end{array}$

France aged 32-62 years, $\mathrm{n}=3237$
Composite score of cognitive Mixed-model analyses and $t$ tests (age, education, sex auditory verbal learning test) psychosocial engaged lifestyle processing speed (WAIS: Digit Symbol Substitution Test) Attentio
(Sternberg's selective attention tests) and health factors, time at examination)

U: 30 years (T0 Cognitive function at T0, T1, T2, T3 Growth curve models (sex 1964, T1 1970, T2 1984, T3 1994) characteristics at $\mathrm{TO}$ (intellectual challenge/ physical hazards/ psychological demanding)

Bosma

et al,

2003; ${ }^{22}$ MAAS study: aged 50 80 Recruited from general practices, $\mathrm{n}=630$

Studies examining work complexity Finkel et al, SATSA, twins, $>50$ $2009^{33} \quad 91$ years, minimum one Sweden cognitive testing, $\mathrm{n}=462$

Mental work demands (Dutch mental complexity work scale)

FU: 3 years (TO 1993; T1 19961998)

CW with data/people/ things (Swedish, US census, DOT)
FU: 16 Five waves: T1 1986-1988; T2 1989-1991: T3 1992-1994;

T5 1999-2001; T6 2002-2004

\section{Cognitive function at T0, T1, T2, T3 Growth curve models (sex,
and change in function} Composite score (non-verba short-term memory and reasoning; WAIS: digit symbol, block design, digit span and picture completion)

Cognitive impairments (10th lowest percentile of composite score: Stroop Color and Word Test; verbal learning test, letter digit coding test; word fluency test)

Level and rate of changes in cognitive function

Verbal ability (information,

synonyms and analogies test) Spatial ability (figure logic, block design, card rotations)

Processing speed (symbol digit and figure identification)

Memory (digit span, picture memory, names and faces)
Intellectual challenge lowered cognitive function compared with manual workers (intercept $=-0.17$, $p<0.001)$;

NS: high physical hazards (intercept= $-0.07, p=0.182)$; psychological demands (intercept $=-0.04, p=0.416$ Persons in jobs with high mental work demands had lower risks of developing cognitive impairments ( $\mathrm{OR}=0.79, \mathrm{Cl} 0.65$ to 0.96 ) ducation, length of foll interval, people with cognitive impairments excluded at baseline)

\section{Latent growth curve model} before and after retirement (education, $\mathrm{n}$ with dementia deleted, no gender differences, practice effects)

\section{CW people}

High CW better verbal ability at retirement (mean intercept PE hig : 53.7; low: 55, $p<0.05$ ) NS after retiremen

High CW better spatial ability at (mean intercept PE difference between high and low: 3.48 , $\mathrm{p}<0.05$ ) and after retirement (mean intercept PE not reported, $p<0.05$ )
Results: change in cognitive function

NS: non-significant results, $\mathrm{p}<0.05$

Greater mental work demands associated with slower rates of decline in episodic memory

before and after retirement

(slope $=0.01, p<0.05,60 \%$ of the variance) and less decline in mental status after retirement (slope $=0.004, p<0.05$ ) than people with lower work demands T1-T2: two highest cognitive stimulation less decline $(T=11.27$, $p<0.001 ; t=14.83, p<0.001$ )

Two lowest cognitive stimulation also less decline $(t=3.30, p<0.01$ $t=8.09, p<0.001$ )

T2-T3: two low cognitive stimulation accelerated decline $(\mathrm{t}=-2.49, \mathrm{p}<0.0126 ; \mathrm{t}=-2.44$ $\mathrm{p}<0.0146)$

NS: two highest cognitive stimulation ( $t=1.0, p=0.32$; $\mathrm{t}=-0.21, \mathrm{p}=84$ )

NS: intellectual challenge (slope= $-0.02, p=0.845$ ); higher physica hazards (slope $=0.06, p=0.598$ ) and psychological demands

(slope $=-0.08, \mathrm{p}=0.394$ ) 


\begin{tabular}{|c|c|c|c|c|c|c|c|}
\hline $\begin{array}{l}\text { Study } \\
\text { Author, } \\
\text { year; } \\
\text { country }\end{array}$ & $\begin{array}{l}\text { Population (age, } \\
\text { inclusion criteria, } \\
\mathrm{n}=\text { number of } \\
\text { participant) }\end{array}$ & Exposure (categories) & $\begin{array}{l}\text { Follow-up in } \\
\text { years (FU) } \\
\text { Waves: year } \\
\text { (T=time, } \\
\text { T0=baseline) }\end{array}$ & $\begin{array}{l}\text { Outcome measurements } \\
\text { Cognitive domain (type of } \\
\text { cognitive test) }\end{array}$ & $\begin{array}{l}\text { Statistical tests and included } \\
\text { covariates (variables) }\end{array}$ & $\begin{array}{l}\text { Results: level of cognitive } \\
\text { function } \\
\text { NS: non-significant results, } \\
\text { p }<0.05\end{array}$ & $\begin{array}{l}\text { Results: change in cognitive } \\
\text { function } \\
\text { NS: non-significant results, } \\
\text { p }<0.05\end{array}$ \\
\hline & & & & & & $\begin{array}{l}\text { High CW better speed at (mean } \\
\text { intercept PE high: } 55.47 \text { and low: } \\
52.91, p<0.05 \text { ) but NS after } \\
\text { retirement } \\
\text { NS: CW people: memory; CW data } \\
\text { or CW things all abilities before and } \\
\text { after retirement }\end{array}$ & $\begin{array}{l}0.13 \text {; low CW: }-0.22, p<0.05) \\
\text { NS: CW people memory or speed } \\
\text { before and after retirement; CW } \\
\text { data, CW things all abilities }\end{array}$ \\
\hline $\begin{array}{l}\text { Schooler } \\
\text { et al } \\
19999^{34} \\
\text { USA }\end{array}$ & $\begin{array}{l}\text { Random selection of } \\
\text { male civilian workers } \\
<65 \text { years, who worked } \\
\text { at all three waves, } \\
\mathrm{n}=160 \text { and spouses, } \\
>10 \mathrm{~h} \text { work per week, in } \\
1974 \text { and } 1994, \mathrm{n}=73\end{array}$ & $\begin{array}{l}\text { CW (self-directed work } \\
\text { and DOT, USA) }\end{array}$ & $\begin{array}{l}\text { F: } 30 \text { years } \\
\text { Three waves: } \\
\text { T0 1964; } \\
\text { T1 1974; } \\
\text { T2 1994-1995 }\end{array}$ & $\begin{array}{l}\text { Intellectual function: Composite } \\
\text { score } \\
\text { (embedded figures test, immediate } \\
\text { recall, category fluency, number } \\
\text { series, ADEPT, PMA, verbal } \\
\text { meaning test, identical pictures test, } \\
\text { different uses test) } \\
\text { Intellectual flexibility (researchers' } \\
\text { rating of intellectual ability and } \\
\text { agreeableness) }\end{array}$ & $\begin{array}{l}\text { Structural equation modelling } \\
\text { (age, gender, education, race, } \\
\text { religious background, national } \\
\text { background, medically disabled } \\
\text { excluded) }\end{array}$ & $\begin{array}{l}\text { CW T1-T3 better intellectual } \\
\text { function at } \mathrm{T} 2(<57 \text { years } \mathrm{SC}=0.11 \\
\mathrm{p}<0.05 ;>56 \text { years } \mathrm{SC}=0.23 \text {, } \\
\mathrm{p}<0.001) \\
\text { Intellectual function } \mathrm{T} 3 \text { and } \mathrm{CW} \mathrm{T} 3 \\
(\mathrm{SC}=0.26, \mathrm{p}<0.01) \\
\mathrm{CW} \mathrm{T} 1 \text { better intellectual flexibility } \\
\mathrm{T} 2(<57 \text { years } \mathrm{SC}=0.26, \mathrm{p}<0.01 \text {; } \\
>56 \text { years } \mathrm{SE}=0.50, \mathrm{p}<0.001) \\
\text { Composite } \mathrm{score} \text { of intellectual } \\
\text { function correlated with intellectual } \\
\text { functioning (CE }=0.87 ; \text { significance } \\
\text { level not reported) }\end{array}$ & \\
\hline \multicolumn{8}{|c|}{ Studies examining Karasek's demand-control model } \\
\hline $\begin{array}{l}\text { Andel et al } \\
2011 ; \\
\text { Sweden }\end{array}$ & $\begin{array}{l}\text { LNU and SWEOLD study: } \\
\text { oldest old; age } 77-99 ; \\
\mathrm{n}=537\end{array}$ & $\begin{array}{l}\text { Self-reported and } \\
\text { occupation-based job } \\
\text { straint; active jobt; } \\
\text { controlt (high/low); } \\
\text { demandst (high/low) }\end{array}$ & $\begin{array}{l}34 \text { years } \\
\text { Three waves: } \\
\text { TO 1968; } \\
\text { T1 1992; } \\
\text { T2 2002 }\end{array}$ & $\begin{array}{l}\text { Function: cognitive function (MMSE) } \\
\text { and cognitive impairment (cut-off } \\
\leq 7 \text { MMSE) }\end{array}$ & $\begin{array}{l}\text { Ordinal logistic regression (age, } \\
\text { sex, education, self-rated health } \\
\text { and year of cognitive screening) }\end{array}$ & $\begin{array}{l}\text { Self-reported exposure: low control } \\
\text { (ref=high control) and high MMSE } \\
\text { (OR=0.71, } p<0.001) \text { NS: control } \\
\text { and impairment; demands, job } \\
\text { strain, active jobs and MMSE and } \\
\text { impairment } \\
\text { Occupation-based exposure: low } \\
\text { job control and high MMSE } \\
\text { (OR=0.63, } p<0.001) \text { and } \\
\text { impairment }(O R=1.86, p<0.002) \text {, } \\
\text { active job and high MMSE } \\
\text { (OR=1.52, } p<0.001) \text { and } \\
\text { impairment }(O R=0.51, p<0.002) \\
\text { NS: job strain, demands } \\
\text { Socioeconomic position } 38 \% \text { of } \\
\text { variance }\end{array}$ & \\
\hline $\begin{array}{l}\text { Elovainio } \\
\text { et } a l_{,} \\
2009 ;^{37} \text { UK }\end{array}$ & $\begin{array}{l}\text { Whitehall II study: civil } \\
\text { servants age } 35- \\
55 \text { years; } 20 \\
\text { London-based civil } \\
\text { service departments; } \\
\mathrm{n}=4146\end{array}$ & $\begin{array}{l}\text { Self-reported } \\
\text { accumulated job straint; } \\
\text { active jobt }\end{array}$ & $\begin{array}{l}18 \text { years } \\
\text { Five waves: } \\
\text { T0 1985-1988; } \\
\text { T1 1989-1990; } \\
\text { T2 1991-1993; } \\
\text { T4 1997-1999; } \\
\text { T6 2003-2004 }\end{array}$ & $\begin{array}{l}\text { Level of short-term memory (20 } \\
\text { word free recall test), inductive } \\
\text { reasoning (AH4-I), vocabulary (Mill } \\
\text { Hill) } \\
\text { Phonemic fluency ('s' words) } \\
\text { semantic fluency ('animal' words) at } \\
\text { T4 and T6 }\end{array}$ & $\begin{array}{l}\text { Linear regression analyses } \\
\text { (education, sex, age, smoking, } \\
\text { alcohol consumption, BMl, } \\
\text { depression, high strain at } \\
\text { baseline, employment grade) }\end{array}$ & $\begin{array}{l}\text { Active job and higher vocabulary } \\
\text { (reference group=no active job) at } \\
\text { T4 (mean T0-T2: } 24.3-24.8 \text {, Cl } \\
24.1-24.7 \text { to } 24.7-25.0 \text { ) higher } \\
\text { phonemic fluency at T4 (mean T0- } \\
\text { T2: } 16.9 \text { to } 17.3, \mathrm{Cl} 16.6-16.9 \text { to } \\
\text { 17.1-17.6) and T6 (mean T0-T2: } \\
\text { 15.5 to } 16.1, \mathrm{Cl} 15.4-15.8 \text { to } \\
\text { 15.7-16.5) }\end{array}$ & $\begin{array}{l}\text { NS: high strain and active job } \\
\text { and vocabulary and phonemic } \\
\text { fluency }\end{array}$ \\
\hline
\end{tabular}




\begin{tabular}{|c|c|c|c|c|c|c|c|}
\hline $\begin{array}{l}\text { Study } \\
\text { Author, } \\
\text { year; } \\
\text { country }\end{array}$ & $\begin{array}{l}\text { Population (age, } \\
\text { inclusion criteria, } \\
\mathrm{n}=\text { number of } \\
\text { participant) }\end{array}$ & Exposure (categories) & $\begin{array}{l}\text { Follow-up in } \\
\text { years (FU) } \\
\text { Waves: year } \\
\text { (T=time, } \\
\text { T0=baseline) }\end{array}$ & $\begin{array}{l}\text { Outcome measurements } \\
\text { Cognitive domain (type of } \\
\text { cognitive test) }\end{array}$ & $\begin{array}{l}\text { Statistical tests and included } \\
\text { covariates (variables) }\end{array}$ & $\begin{array}{l}\text { Results: level of cognitive } \\
\text { function } \\
\text { NS: non-significant results, } \\
\text { p }<0.05\end{array}$ & $\begin{array}{l}\text { Results: change in cognitive } \\
\text { function } \\
\text { NS: non-significant results, } \\
p<0.05\end{array}$ \\
\hline & & & & & & $\begin{array}{l}\text { NS: high-strain job and memory, } \\
\text { reasoning, phonemic, semantic } \\
\text { fluency; active job and memory, } \\
\text { reasoning, semantic fluency at T4 } \\
\text { and T6, vocabulary at T6 after } \\
\text { adjusting for employment grade }\end{array}$ & \\
\hline $\begin{array}{l}\text { Yu et al, } \\
2009:_{i}^{40} \\
\text { USA }\end{array}$ & $\begin{array}{l}\text { Seattle Longitudinal } \\
\text { Study: mean age } \\
53 \text { years; middle class; } \\
\text { white; } n=626\end{array}$ & $\begin{array}{l}\text { Self-reported autonomy, } \\
\text { work control and } \\
\text { innovation }\end{array}$ & $\begin{array}{l}14 \text { years } \\
\text { Three waves } \\
\text { T1 1984; } \\
\text { T2 1991; } \\
\text { T3 } 1998\end{array}$ & $\begin{array}{l}\text { Level of verbal memory (word } \\
\text { fluency, immediate recall and } \\
\text { delayed recall), inductive reasoning } \\
\text { (PMA, ADEPT-letter, word series, } \\
\text { ETS) }\end{array}$ & $\begin{array}{l}\text { Growth curve models (age, sex, } \\
\text { education, income, dementia) }\end{array}$ & $\begin{array}{l}\text { High control better verbal } \\
\text { (estimate }=0.15, p<0.01 \text { ) and } \\
\text { inductive reasoning } \\
\text { (estimate }=0.15, p<0.01 \text { ) at T3 } \\
\text { NS: autonomy, innovation and } \\
\text { inductive reasoning or verbal } \\
\text { memory }\end{array}$ & $\begin{array}{l}\text { Work control increase memory } \\
\text { score }(t \text { score }=0.13, p<0.05) \text { and } \\
\text { inductive reasoning (t score }=0.14 \\
p<0.05) \\
\text { NS: Autonomy, innovation and } \\
\text { inductive reasoning or verbal } \\
\text { memory }\end{array}$ \\
\hline \multicolumn{8}{|c|}{ Study examining organisational justice } \\
\hline $\begin{array}{l}\text { Elovainio } \\
\text { et al, } \\
2012 ;{ }^{38} \text { UK }\end{array}$ & $\begin{array}{l}\text { Whitehall II study: civil } \\
\text { servants age } 35- \\
55 \text { years; } 20 \\
\text { London-based civil } \\
\text { service departments; } \\
\mathrm{n}=4531\end{array}$ & $\begin{array}{l}\text { Self-reported } \\
\text { organisational justice at } \\
\text { T0 and T1 }\end{array}$ & $\begin{array}{l}\text { FU: } 18 \text { years; } \\
\text { Five waves: } \\
\text { TO 1985-1988; } \\
\text { T1 1989-1990; } \\
\text { T2 1991-1993; } \\
\text { T4 1997-1999; } \\
\text { T6 2003-2004 }\end{array}$ & $\begin{array}{l}\text { Level of short-term memory ( } 20 \\
\text { word free recall test), inductive } \\
\text { reasoning (AH4-I), vocabulary (Mill } \\
\text { Hill) } \\
\text { Phonemic fluency ('s' words), } \\
\text { semantic fluency ('animal' words) at } \\
\text { T4 and T6 and change in level of } \\
\text { vocabulary and phonemic fluency } \\
\text { (T6-T4) }\end{array}$ & $\begin{array}{l}\text { Linear regression analyses (age, } \\
\text { sex, employment grade, } \\
\text { behavioural risk, depressive } \\
\text { symptoms, hypertension and } \\
\text { high job strain) }\end{array}$ & $\begin{array}{l}\text { Lower mean level of justice } \\
\text { associated with lower levels of } \\
\text { short-term memory (T4; } B=-0.04 \text {, } \\
p<0.003 ; \mathrm{T} 6 ;-0.04, p<0.008) \text {, } \\
\text { reasoning (T4; } B=-0.04, p<0.038 \text {; } \\
\text { T6; }-0.04, p<0.038) \text {, vocabulary } \\
\text { (T4; } B=-0.05, p<0.001 ; T 6 ;-0.04 \text {, } \\
p<0.05) \text {, phonemic (T4; } B=-0.04 \text {, } \\
p<0.03 ; \text { T6; }-0.04, p<0.011) \\
\text { semantic (T4; } B=-0.04, p<0.047 \text {; } \\
\text { T6; }-0.03, p<0.031 \text { ) }\end{array}$ & \\
\hline \multicolumn{8}{|c|}{ Study examining working time } \\
\hline $\begin{array}{l}\text { Virtanen } \\
\text { et al, } \\
2009_{;}^{39} \\
\text { UK; } \\
\text { Moderate }\end{array}$ & $\begin{array}{l}\text { Whitehall II study: civil } \\
\text { servants; age 45- } \\
66 \text { years; } 20 \\
\text { London-based civil } \\
\text { service departments; } \\
\mathrm{n}=2214\end{array}$ & $\begin{array}{l}\text { Self-reported actual } \\
\text { weekly working hours } \\
\text { (long: }>55 \mathrm{~h} \text {, medium: } \\
41-55 \text {, normal: } \leq 40 \text { ) }\end{array}$ & $\begin{array}{l}5 \text { years } \\
\text { Two waves: } \\
\text { T5 1997-1999; } \\
\text { T7 2002-2004 }\end{array}$ & $\begin{array}{l}\text { Level of and change in inductive } \\
\text { reasoning T7-T5 (AH 4-l; short term) } \\
\text { and level of short-term memory ( } 20 \\
\text { word free recall test), vocabulary } \\
\text { (Mill Hill) } \\
\text { Phonemic fluency ('s' words), } \\
\text { semantic fluency ('animal' words) } \\
\text { at T7 }\end{array}$ & $\begin{array}{l}\text { Multiple analysis of covariance } \\
\text { (age, sex, marital status, } \\
\text { employment status, } \\
\text { occupational grade, education, } \\
\text { income, physical health, } \\
\text { psychological distress, anxiety, } \\
\text { sleep problems, health risk } \\
\text { behaviours, social support, } \\
\text { family stress and job strain) }\end{array}$ & $\begin{array}{l}\text { Overall association of long working } \\
\text { hours and poorer cognitive function } \\
\text { ( } \mathrm{p}=0.037 \text {, estimate not reported). } \\
\text { Long working hours (REF=normal) } \\
\text { poorer reasoning (mean } \\
\text { difference }=-1.14, p=0.040 \text { ) } \\
\text { vocabulary (mean difference }= \\
-0.38, p<0.032 \text { ) } \\
\text { NS: memory, phonemic and } \\
\text { semantic fluency } \\
\text { Medium working hours } \\
\text { (REF=normal) poorer vocabulary } \\
\text { (mean difference }=-0.23, p=0.02 \text { ) } \\
\text { NS: memory, reasoning, phonemic } \\
\text { and semantic fluency }\end{array}$ & $\begin{array}{l}\text { Overall association of working } \\
\text { hours and change in score } \\
\text { ( } p=0.044 \text {, estimate not reported) } \\
\text { Long working hours } \\
\text { (REF=normal) decline in } \\
\text { reasoning (mean difference= } \\
-1.13, p<0.007 \text { ) } \\
\text { Medium long working hours } \\
\text { (REF=normal) decline in } \\
\text { reasoning (mean difference= } \\
-0.46, p<0.046 \text { ) }\end{array}$ \\
\hline
\end{tabular}

tMeasured according to Karasek's $s^{13}$ two dimensions: job control and job demands. Active job is defined as a high degree of job control and demands; job strain is defined as a low degree of job control and a high degree of demands. ADEPT, A Developmental English Proficiency Test (similar to Primary Mental Ability Test); AH4, Alice Heim Test; B, $\beta$ standardised regression coefficient; BMI, body mass index; CW, complexity of work; DOT, Dictionary of Occupational Titles, US

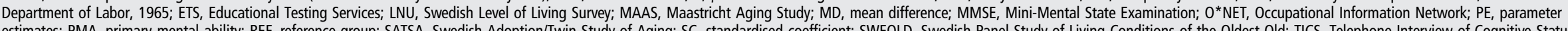

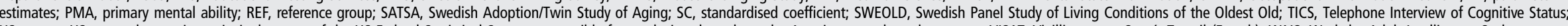


between declines of verbal and processing speed were found after retirement, indicating that only participants in high complexity jobs experienced a decline after retirement.

Schooler et al's ${ }^{34}$ made a 30-year follow-up of Kohn and Schooler's ${ }^{35}$ original study. The original study found that male workers with occupations involving complex work with people or data had a high level of intellectual flexibility. They also found that older workers had a higher flexibility than younger workers, and that the substantial complexity of the job was influenced by the degree of intellectual flexibility. Intellectual flexibility was mainly based on the researcher's interpretation of the participant's intellectual ability and therefore highly prone to bias. The follow-up study did not distinguish between the three dimensions of occupational complexity-people, data or things-however, standardised cognitive tests were used and the composite scores correlated with the initial measurements of intellectual flexibility.

The risk of selection bias, survival of the cohort bias and limited external validity applied to all the studies. These studies were nevertheless all of moderate quality because they accounted for most of these biases by their study designs and thorough analyses.

\section{Synthesis of evidence}

Two studies of moderate quality ${ }^{33} 34$ provided moderate evidence that a high complexity of main lifetime occupation improved cognitive function over a period ranging from 12 to 30 years. We found weak evidence from one study of moderate quality $^{33}$ that complex work with people diminished decline of verbal ability in the period up until retirement and an accelerated decline of spatial ability after retirement.

\section{Review of studies measuring exposure to psychosocial work environmental factors}

Five studies ${ }^{36-40}$ examined whether exposure to different work environmental conditions influenced the level or decline of cognitive abilities (table 2).

Three studies examined Karasek's job strain and active job dimensions. After adjusting the results for employment grade, Elovainio $e t ~ a l^{37}$ found no effect of cumulative exposure to job strain on five different cognitive domains. They did find that cumulative exposure to an active job increased the levels of two out of five different examined cognitive domains. They found no effect of exposure to job strain or active job on decline of verbal meaning or phonemic fluency in the period of 12 years. Andel $e t a l^{36}$ also failed to find an effect of job strain on the levels of overall cognitive function nor found that an active job consistently influenced cognitive function. A low level of job control was associated with a lower level of cognitive function in a period of 32 years, regardless of whether job control was self-reported or examined via occupational titles. Yu et $a l^{40}$ also showed that a high level of job control increased the levels of verbal memory and inductive reasoning and improved these domains in a period of 14 years.

Elovainio et $a l^{38}$ found that a low level of organisational justice had adverse effect on cognitive function-the impact on cognitive decline was not examined.

Virtanen et $a l^{39}$ showed that long working hours lead to an overall poorer cognitive functioning and a faster rate of decline of reasoning. Whether long work hours also lead to an accelerated decline of vocabulary, phonemic and semantic fluency were not examined.

\section{Synthesis}

We found no evidence that job strain was prospectively associated with lower levels of cognitive function and conflicting evidence as to whether active jobs improved levels of cognitive function. $^{36} 37$ We found moderate evidence that job control improved cognitive function ${ }^{36} 40$ and weak evidence that job control improved cognitive ability in a period of 14 years. ${ }^{36}$

We found weak evidence that low organisational justice lead to lower levels of short-term memory, inductive reasoning and verbal fluency, but insufficient evidence with regards to cognitive decline. ${ }^{38}$

We found weak evidence ${ }^{39}$ that working long hours were prospectively associated with a lower level of inductive reasoning and an accelerated decline of inductive reasoning.

\section{DISCUSSION}

This systematic review showed evidence that workers exposed to high levels of mental work demands, occupational complexity or job control had higher levels of cognitive function when measured at midlife or late life, than workers exposed to low levels. Nevertheless, the evidence to clarify whether these psychosocial work factors also affected the rate of age-related cognitive decline was conflicting, weak or insufficient. We found no, and insufficient evidence, of an impact of job strain or active job on cognitive function. We found weak evidence that a low level of organisational justice lead to lower cognitive function and long working hours accelerated cognitive decline.

Our findings challenge the conclusion of a prior systematic review $^{20}$ stating that psychosocial work conditions can protect against cognitive decline. By contrast to the previous review, our review distinguished between outcomes measured at one point in time and changes over time. Reconsidering the evidence from these alternative viewpoints, it became clear that only few studies of high quality had examined the impact of psychosocial work conditions on age-related decline. The available evidence mostly supported theoretical mechanisms underlying the theory of brain reserve. Since we found no evidence of differential preservation, ${ }^{41}$ the evidence to suggest that different psychosocial work factors can protect against cognitive decline remained inconclusive.

The same conclusions have been made in other research areas. Salthouse ${ }^{12}$ concluded in a review that there was evidence to support the view that mental activity could improve the level of functioning but not slow the rate of decline over time. Nevertheless, for several reasons, it is too early to rule out that the psychosocial work environment can play a key role in cognitive ageing processes.

Although the evidence regarding cognitive decline was insufficient, conflicting or weak, it did not necessarily reflect 'no evidence'. Also, the heterogeneity among studies challenged proper comparison of findings. A total of 7 of the 11 studies included in the synthesis had measured cognitive decline, but the examined populations, age groups, exposures, cognitive tests, follow-up periods and statistical methods varied greatly across studies.

The studies measured work exposures by either self-report measurements or classification systems identifying job content from job titles. The studies mainly used validated scales and by contrast to classification systems, self-ratings can detect individual variability of job demands across different work contexts. However, self-report bias may have occurred. For example, selfratings of mental work demands could have been subject to social desirability bias resulting in exaggerated responses. 
However, cohort effects and difference in cognitive performance at different ages were more likely to explain the conflicting findings with regards to mental work demands. ${ }^{42}$ One study found no effect of the impact of work demands in a cohort of participants born in 1914 on cognitive decline when examined in participant's from age 70 to 80 years. ${ }^{32}$ Yet, two studies that examined participants born after 1940 and who were between ages 41 and 61 found a protective effect. ${ }^{30} 31$

Finkel et $a l^{33}$ found that exposure to complex work with people, but not data or things, was associated with a slower rate of decline of verbal ability before retirement, but not a slower rate of spatial ability, processing speed or memory. After retirement, the impact on the different cognitive domains changed. These results remain speculative as individual's aged $40-50$ years may be less vulnerable to cognitive decline than individuals aged 60-70 years. ${ }^{43}$ Nevertheless, the findings indicated that the rate of cognitive decline varied according to the nature of the job and the related cognitive domain along with the intensity of the work exposure.

Cohort studies are particularly vulnerable to selection and survival of the cohort bias. Since all the included studies were longitudinal cohort studies, the quality assessment criteria addressed these biases, ${ }^{24}{ }^{44}$ and the studies that had not adequately minimised the risk of these biases were given lower scores. All the studies included in the synthesis had accounted for selection and survival of the cohort bias along with main confounders, such as sex, age, education or occupational grade. The majority of studies had also accounted for confounding health factors. However, few studies had controlled for prior cognitive ability or practice effects ${ }^{45}$ and although we accounted for these in the overall quality assessment, we may have overestimated the protective impact of work factors on cognitive decline.

Prior, cognitive ability and education weakened the protective associations. In accordance with the theory of cognitive reserve, these findings indicated that factors determined early in life along with competences obtained later in life remained essential aspects of cognitive ageing processes. It is likely that the relationship between work complexity and cognitive ageing is reciprocal $;{ }^{34}$ prior ability and education select individuals into high complexity jobs, but high complexity jobs also help individuals to obtain competences and maintain cognitive ability later in life.

Future studies need better theoretical and methodological frameworks to clarify whether the brain is more flexible than previously assumed. ${ }^{18} 19$ Two aspects could advantageously be pursued further. As opposed to confounders, prior cognitive ability and education could be examined as mediating factors of the level of work demands and complexity obtained later in life. Future studies need to include intraindividual measurements of cognitive change and examine how changes in the intensity of work exposures influence the rate of decline of different cognitive domains.

\section{CONCLUSION}

The number of good quality studies examining cognitive decline was scarce and it remained speculative whether job control, job demands or occupational complexity protected against cognitive decline. The conclusions of a previous review and the public health implications should be redefined accordingly. By examining changes in mental work exposures along with intraindividual cognitive decline, future studies can reveal whether workers gain more cognitive reserve in midlife and late life than the available evidence currently suggests.
Acknowledgements The authors thank Elizabeth Bengtsen at NRCWE for undertaking the literature search. They also thank Erik Lykke Mortensen from Copenhagen University, Pernille Tufte at the Dane Age Association, Niels Kasper Jørgensen at the Danish Dementia Research Center and Hester Johnstone Lipscomb at Duke University for their contributions to the discussion of this review.

Contributors MAN wrote the manuscript, codeveloped the idea and was responsible for the design, execution, synthesis, interpretation and discussion of findings. VB was responsible for the idea and along with AM codeveloped the design and participated in the execution and interpretation of the results.

Funding This work was supported by the Danish Working Environment Research Fund (grant number 20110038063).

Competing interests None declared.

Provenance and peer review Not commissioned; externally peer reviewed.

Open Access This is an Open Access article distributed in accordance with the Creative Commons Attribution Non Commercial (CC BY-NC 4.0) license, which permits others to distribute, remix, adapt, build upon this work non-commercially, and license their derivative works on different terms, provided the original work is properly cited and the use is non-commercial. See: http://creativecommons.org/ licenses/by-nc/4.0/

\section{REFERENCES}

1 OECD. Working paper awp 3.4. retirement income systems: the Reform Process Across OECD Countries. OECD, 1998.

2 The Nordic Council of Ministers. The ageing and the labour market in the Nordic countries: a literature review. Tema Nord, 2004.

3 Jekel K, Damian M, Wattmo C, et al. Mild cognitive impairment and deficits in instrumental activities of daily living: a systematic review. Alzheimers Res Ther 2015;7:17.

4 Teng E, Tassniyom K, Lu PH. Reduced quality-of-life ratings in mild cognitive impairment: analyses of subject and informant responses. Am J Geriatr Psychiatry 2012;20:1016-25.

5 Salthouse T. Developmental influences on adult intelligence: the Seattle Longitudinal Study. Intelligence 2005;33:551-4.

6 Salthouse TA. When does age-related cognitive decline begin? Neurobiol Aging 2009;30:507-14.

7 Salthouse TA. Selective review of cognitive aging. J Int Neuropsychol Soc 2010;16:754-60.

8 Salthouse T. Consequences of age-related cognitive declines. Annu Rev Psychol 2012;63:201-26.

9 Brun E, Milczarek M. European risk observatory report: expert forecast on emerging psychosocial risks related to occupational safety and health. Belgium: European Agency for Safety and Health at Work, 2007.

10 Hunt E, Madhyastha TM. Cognitive demands of the workplace. J Neurosci Psychol Econ 2012;5:18-37.

11 IImarinen JE. Aging workers. Occup Environ Med 2001;58:546-52.

12 Salthouse TA. Mental exercise and mental aging evaluating the validity of the "use it or lose it" hypothesis. Perspect Psychol Sci 2006;1:68-87.

13 Karasek RA. Job demands, job decision latitude, and mental strain: implications for job redesign. Adm Sci Q 1979;24:285-308.

14 Hausser JA, Mojzisch A, Niesel M, et al. Ten years on: a review of recent research on the Job Demand-Control (-Support) model and psychological well-being. Work Stress 2010;24:1-35.

15 Deligkaris P, Panagopoulou E, Montgomery AJ, et al. Job burnout and cognitive functioning: a systematic review. Work Stress 2014;28:107-23.

16 Katzman R. Education and the prevalence of dementia and Alzheimer's disease. Neurology 1993;43:13-20.

$17 \mathrm{Ng}$ TWH, Feldman DC. How do within-person changes due to aging affect job performance? J Vocat Behav 2013;83:500-13.

18 Stern Y. Cognitive reserve. Neuropsychologia 2009;47:2015-28.

19 Stern Y. Cognitive reserve in ageing and Alzheimer's disease. Lancet Neurol 2012;11:1006-12.

20 Then FS, Luck T, Luppa M, et al. Systematic review of the effect of the psychosocial working environment on cognition and dementia. Occup Environ Med 2014;71:358-65.

21 Andel R, Kåreholt I, Parker MG, et al. Complexity of primary lifetime occupation and cognition in advanced old age. J Aging Health 2007;19:397-415.

22 Bosma H, van Boxtel MP, Ponds RW, et al. Mental work demands protect against cognitive impairment: MAAS prospective cohort study. Exp Aging Res 2003;29:33-45.

23 Moher D, Liberati A, Tetzlaff J, et al. Preferred reporting items for systematic reviews and meta-analyses: the PRISMA statement. J Clin Epidemiol 2009;62:1006-12.

24 CASP. Skills Program CASP Cohort study checklist. 13 A.D.

25 van der Noordt M, IJzelenberg H, Droomers M, et al. Health effects of employment: a systematic review of prospective studies. Occup Environ Med 2014;71:730-6. 
26 Sanderson S, Tatt ID, Higgins JPT. Tools for assessing quality and susceptibility to bias in observational studies in epidemiology: a systematic review and annotated bibliography. Int J Epidemiol 2007;36:666-76.

27 West S, King V, Carey TS, et al. Systems to rate the strength of scientific evidence. Rockville, MD: Agency for Healthcare Research and Quality: AHRQ Publication, 2002.

28 Cain PS, Treiman DJ. The dictionary of occupational titles as a source of occupational data. Am Sociol Rev 1981;46:253-78.

29 Vijverberg WPM, Hartog J. On simplifying the structure of labour demand: an analysis of the DOT data. IZA Discussion Paper. 2005;No. 1809.

30 Fisher GG, Stachowski A, Infurna FJ, et al. Mental work demands, retirement, and longitudinal trajectories of cognitive functioning. J Occup Health Psychol 2014;19:231-42.

31 Marquie JC, Duarte LR, Bessières $P$, et al. Higher mental stimulation at work is associated with improved cognitive functioning in both young and older workers. Ergonomics 2010;53:1287-301.

32 Gow AJ, Avlund K, Mortensen EL. Occupational characteristics and cognitive aging in the Glostrup 1914 cohort. J Gerontol B Psychol Sci Soc Sci 2014;69:228-36.

33 Finkel $D$, Andel R, Gatz M, et al. The role of occupational complexity in trajectories of cognitive aging before and after retirement. Psychol Aging 2009;24:563-73.

34 Schooler C, Mulatu MS, Oates G. The continuing effects of substantively complex work on the intellectual functioning of older workers. Psychol Aging 1999:14:483-506.

35 Kohn M, Schooler C. The reciprocal effects of the substantive complexity of work and intellectual flexibility: a longitudinal assessment. AJS 1978;84:24-52.
36 Andel R, Crowe M, Kaareholt I, et al. Indicators of job strain at midlife and cognitive functioning in advanced old age. J Gerontol B Psychol Sci Soc Sci 2011;66B:287-91.

37 Elovainio $M$, Ferrie JE, Singh-Manoux $A$, et al. Cumulative exposure to high-strain and active jobs as predictors of cognitive function: the Whitehall II study. Occup Environ Med 2009;66:32-7.

38 Elovainio $M$, Singh-Manoux A, Ferrie JE, et al. Organisational justice and cognitive function in middle-aged employees: the Whitehall II study. J Epidemiol Community Health 2012;66:552-6.

39 Virtanen $M$, Singh-Manoux A, Ferrie JE, et al. Long working hours and cognitive function: the Whitehall II Study. Am J Epidemiol 2009;169:596-605.

40 Yu F, Ryan LH, Schaie KW, et al. Factors associated with cognition in adults: the Seattle Longitudinal Study. Res Nurs Health 2009;32:540-50.

41 Salthouse TA. Does the direction and magnitude of cognitive change depend on initial level of ability? Intelligence 2012;40:352-61.

42 Salthouse TA. Within-cohort age-related differences in cognitive functioning. Psychol Sci 2013;24:123-30.

43 Salthouse TA. Influence of age on practice effects in longitudinal neurocognitive change. Neuropsychology 2010;24:563-72.

44 Des Jarlais DC, Lyles C, Crepaz N. Improving the reporting quality of nonrandomized evaluations of behavioral and public health interventions: the TREND statement. Am J Public Health 2004;94:361-6.

45 Salthouse TA. Robust cognitive change. J Int Neuropsychol Soc 2012;18:749-56. 